\title{
Hypersensitivity to parenteral antibiotics in patients with cystic fibrosis
}

\author{
Jobst Roehmel', Carsten Schwarz, Anne Mehl, Philippe Stock, Doris Staab \\ From 6th Drug Hypersensitivity Meeting (DHM 6) \\ Bern, Switzerland. 9-12 April 2014
}

\section{Background}

Hypersensitivity reactions to parenteral administered antibiotics (HRPA) are a substantial problem in managing pulmonary disease in Cystic Fibrosis (CF), especially in advanced CF. This group of patients requires a life long antibiotic treatment with extremely high cumulative doses compared to other patients. In our daily routine we observed a growing number of hypersensitivities. Therefore we conducted this observational study to assess HRPA's impact on the daily clinical work with CF, as well as it's nature, frequency and predisposing risk factors.

\section{Methods}

By reviewing medical records and conducting interviews, age, sex, FEV1, $\triangle$ F508-genotype, onset and duration of pseudomonal colonisation, allergy history (including IgE serum levels, past ABPA and results of screening tests for inhalative aeroallergens), parenteral antibiotic exposure and HRPA (timing, symptoms and treatment) were recorded. Included were all paediatric and adult patients at our centre with $>3$ intravenous antibiotic treatment courses.

\section{Results}

Of 100 patients included in the study, 60 had $\geq 1$ HRPA. Overall, 3205 antibiotic courses with 185 HRPA were ascertained. 15\% of HRPA met the criteria for anaphylaxis. Symptoms were mostly dermal (53\%). $81 \%$ of all and $80 \%$ of anaphylactic HRPA occurred during days 1-4. Approximately $10 \%$ of all treatment courses with cefepime and piperacillin/tazobactam caused HRPA. The number of years with pseudomonal colonisation and the cumulative annual exposure of the given antibiotic were significant risk factors for HRPA in our patient cohort.

\footnotetext{
Charité Universitätsmedizin Berlin, Pediatrics, Division of Pneumonology \&
} Immunology, Germany

\section{and take full advantage of:}

- Convenient online submission

- Thorough peer review

- No space constraints or color figure charges

- Immediate publication on acceptance

- Inclusion in PubMed, CAS, Scopus and Google Scholar

- Research which is freely available for redistribution Submit your manuscript at
www.biomedcentral.com/submit C BioMed Central 